\title{
Serological signature of tick-borne pathogens in Scandinavian brown bears over two decades
}

\author{
Lye Paillard ${ }^{1}$, Krista L. Jones², Alina L. Evans², Jérémy Berret ${ }^{1}$, Maxime Jacquet ${ }^{1}$, Reto Lienhard ${ }^{3}$, \\ Mahmoud Bouzelboudjen ${ }^{4}$, Jon M. Arnemo ${ }^{2,5}$, Jon E. Swenson ${ }^{6,7}$ and Maarten J. Voordouw ${ }^{1 *}$
}

\begin{abstract}
Background: Anthropogenic disturbances are changing the geographic distribution of ticks and tick-borne diseases. Over the last few decades, the tick /xodes ricinus has expanded its range and abundance considerably in northern Europe. Concurrently, the incidence of tick-borne diseases, such as Lyme borreliosis and tick-borne encephalitis, has increased in the human populations of the Scandinavian countries.

Methods: Wildlife populations can serve as sentinels for changes in the distribution of tick-borne diseases. We used serum samples from a long-term study on the Scandinavian brown bear, Ursus arctos, and standard immunological methods to test whether exposure to Borrelia burgdorferi sensu lato, the causative agent of Lyme borreliosis, and tick-borne encephalitis virus (TBEV) had increased over time. Bears had been sampled over a period of 18 years (1995-2012) from a southern area, where Ixodes ricinus ticks are present, and a northern area where ticks are uncommon or absent.

Results: Bears had high levels of IgG antibodies against B. burgdorferi sensu lato but not TBEV. Bears at the southern area had higher values of anti-Borrelia lgG antibodies than bears at the northern area. Over the duration of the study, the value of anti-Borrelia IgG antibodies increased in the southern area but not the northern area. Anti-Borrelia lgG antibodies increased with the age of the bear but declined in the oldest age classes.

Conclusions: Our study is consistent with the view that ticks and tick-borne pathogens are expanding their abundance and prevalence in Scandinavia. Long-term serological monitoring of large mammals can provide insight into how anthropogenic disturbances are changing the distribution of ticks and tick-borne diseases.
\end{abstract}

Keywords: Borrelia burgdorferi, Ixodes ricinus, Lyme disease, Scandinavia, Serology, Tick-borne diseases, Tick-borne encephalitis virus, Ursus arctos, Vector-borne diseases, Zoonoses

\section{Background}

The incidence of tick-borne diseases, such as Lyme borreliosis (LB) and tick-borne encephalitis (TBE), has increased over the last few decades in a number of European countries [1-3]. One explanation for the increase in tick-borne infections is that the distributional area and abundance of the principal vector, Ixodes ricinus, have increased [4-8]. Consistent with this

\footnotetext{
* Correspondence: maarten.voordouw@unine.ch

'Laboratory of Ecology and Evolution of Parasites, Institute of Biology, University of Neuchâtel, Rue Emile-Argand 11, 2000 Neuchâtel, Switzerland Full list of author information is available at the end of the article
}

explanation, studies in Norway and Sweden have shown that the abundance and prevalence of ticks and tickborne diseases have increased during this time $[9,10]$. The distribution of ticks and tick-borne diseases has expanded northward, to higher altitudes, and to new inland regions [9]. In addition, ticks have increased in abundance where they were already present in central and south Sweden [10,11]. Studies in other parts of the world also have reported changes in the distribution of ticks and tick-borne diseases [12-15].

Climate change could drive changes in the distribution of ticks because these arthropods are very sensitive to temperature and humidity $[4,7]$. In southern Sweden, 
the increase in the incidence of LB was positively correlated with a rise in monthly mean temperature [16]. Climate change could also influence the distribution and abundance of ticks and tick-borne diseases via indirect effects on vegetation $[15,17]$ and important reservoir hosts like rodents [1]. The climate change hypothesis for the emergence of tick-borne diseases in Europe is controversial [2, 7, 18, 19]. Alternative anthropogenic explanations include changes in agriculture and land use that have increased the amount of suitable tick habitat $[3,19]$. Additional explanations include improved reporting, diagnosis, and awareness of tick-borne diseases $[9,20]$, changes in human behaviour that increase contact with ticks $[7,16,19]$, and even the sociopolitical changes in Eastern Europe following the collapse of communism $[3,21]$.

Immunological methods are widely used to determine whether vertebrate populations have been exposed to tick-borne pathogens [22-24]. The study of changes in the IgG antibody response over time can provide insight into the temporal dynamics of tick-borne diseases [25]. The purpose of our study was to test whether the observed increase in the incidence of tick-borne diseases over the last two decades in Scandinavia could be detected in wild animal sera.

To address this question, we used standard immunological methods to quantify the IgG antibody response against two common tick-borne pathogens in the brown bear (Ursus arctos). Long-lived mammals, such as brown bears, can be repeatedly exposed to ticks and are therefore expected to amplify the immunological signature of tickborne pathogens. Previous studies in Europe and North America have shown that bears can be used as sentinels for tick-borne diseases [26-29]. We investigated the strength of the IgG antibody response against the spirochete bacterium Borrelia burgdorferi sensu lato (s. 1.), the causative agent of Lyme borreliosis, and the tick-borne encephalitis virus (TBEV). We chose these two tick-borne pathogens because they are present in Scandinavia $[2,17$, $18,30-34]$ and because reliable ELISA tests are commercially available [35-37].

The brown bears were captured at a southern and a northern area in Sweden over a period of 18 years (1995 to 2012). In the southern area, populations of I. ricinus have increased substantially from the early 1990s to 2008 [10]. In the northern area, by contrast, there have been much fewer reports of I. ricinus as of 2008 [10]. We therefore predicted that the immune response against tickborne pathogens would be much stronger in bears from the southern area than bears from the northern area. We also predicted that the immune response against tickborne pathogens in bear sera would increase over the 18 years of the study in the southern area but not the northern area.

\section{Methods}

\section{Collection of bear serum samples}

The serum samples were obtained from a long-term study of the brown bear in Sweden. These samples spanned 18 years (1995 to 2012) and came from two distinct regions that are approximately $600 \mathrm{~km}$ apart. The southern area was centred in Dalarna and Gävleborg counties in central Sweden $\left(61^{\circ} 30^{\prime} 0^{\prime \prime} \mathrm{N}, 17^{\circ} 0^{\prime} 0^{\prime \prime} \mathrm{E}\right)$, with a rolling landscape of coniferous forest dominated by commercial plantations of Scots pine (Pinus sylvestris) and Norway spruce (Picea abies). The northern area, centred in Norrbotten County $\left(66^{\circ} 36^{\prime} 23^{\prime \prime} \mathrm{N}, 19^{\circ} 49^{\prime} 23^{\prime \prime} \mathrm{E}\right)$, is mountainous, with altitudes up to $2000 \mathrm{~m}$ and is covered by coniferous forest of Scots pine and Norway spruce at lower altitudes and subalpine forests dominated by birch (Betula pubescens) and willows (Salix spp.) at higher altitudes (Fig. 1). Details of how the bears were captured have been described elsewhere [38]. Briefly, bears were immobilized by darting from helicopter in the early spring upon emergence from their winter dens. We determined the sex and age of the individuals, collected blood samples, and gave them a unique identification marking. We combined our data into five age groups: yearlings ( $0-1$ years), juveniles ( $2-3$ years), young adults (4-9 years), adults (10-14 years), and old adults (15-29 years). Our data set contained 1,172 serum samples collected from 569 individual bears (mean $=2.06$ samples/bear; range $=1$ to 9 samples/bear). The bear serum samples were kept at $-20^{\circ} \mathrm{C}$ until further analysis.

\section{Detection of antibodies against Borrelia pathogens}

We used an ELISA assay (Borrelia microplate IgG) to test whether the bears had developed specific antibodies against Borrelia pathogens. The 1172 bear serum samples were randomly assigned to one of 14 96-well commercial ELISA plates (Virion; SERION ELISA). Each ELISA plate contained 84 wild bear serum samples, four positive controls (sera from laboratory mice experimentally infected with B. afzelii), four negative controls (sera from uninfected laboratory mice), and four bear serum samples from zoological parks. The serum samples from the zoo bears and the positive and negative controls functioned as a quality control of the ELISA assay. The laboratory mice (positive controls) had been infected with $B$. afzelii by infesting them with $B$. afzelii-infected $I$. ricinus nymphs (unpublished data). To determine the repeatability of the ELISA assay, we also repeated the assay for one randomly selected plate.

\section{Ethical approval}

The Ethical Committee on Animal Experiments, Uppsala, Sweden (\# C 7/12) and the National Animal Research Authority, Oslo, Norway (\# 2013/33387) approved the sampling of blood from captured bears. All experiments involving mice respected the Swiss legislation on animal experimentation and were authorized by the Veterinary 


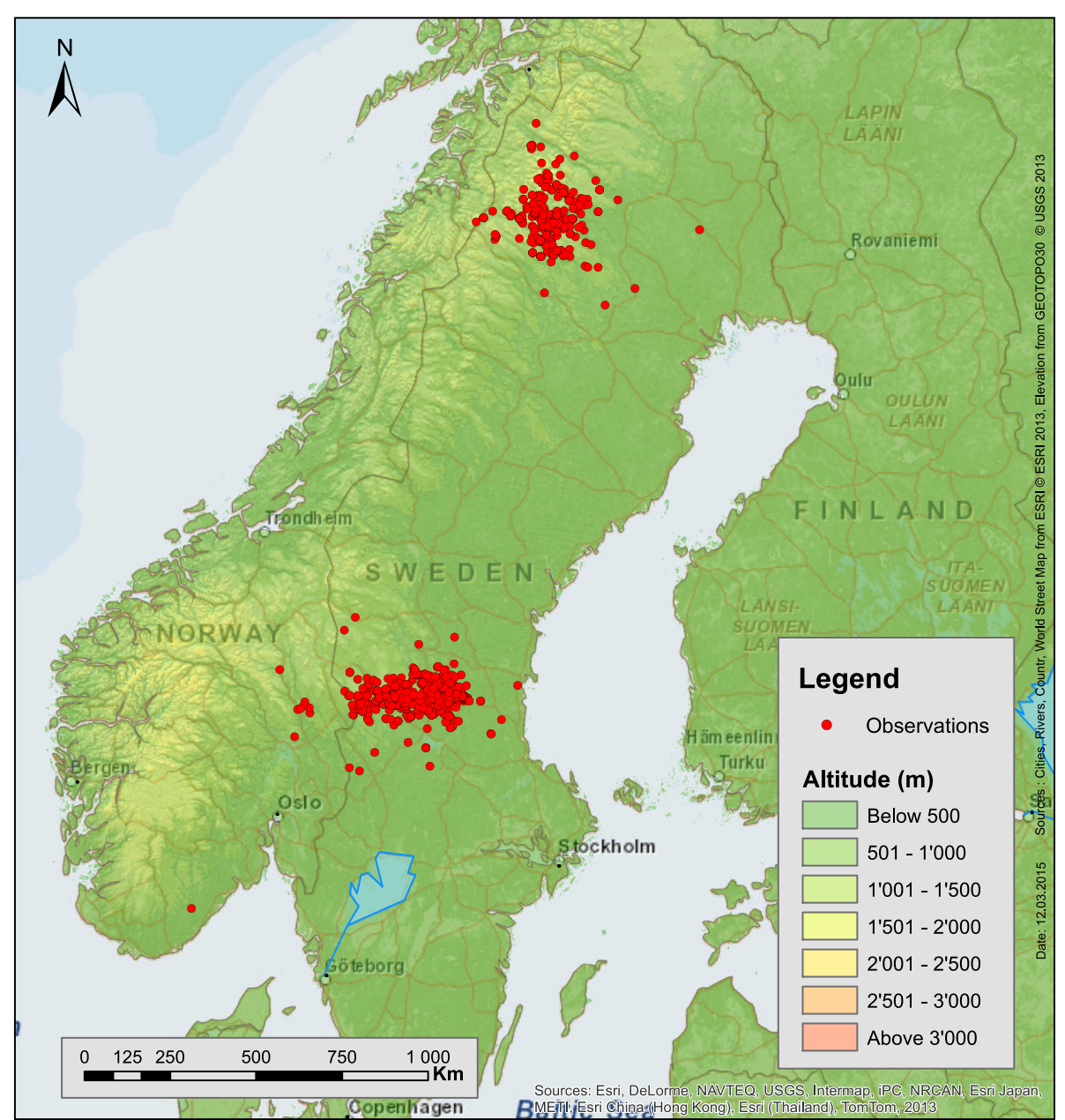

Fig. 1 Map showing the study area in Sweden. Map showing the geographic location of the northern and southern area in Scandinavia where the wild brown bears were captured. Each bear serum sample is represented by one dot

Service of the Canton of Neuchâtel (Authorization number NE2/2012).

Most serological studies on bears and other wild animals use serum dilutions of 1:50 to 1:200 [39-44]. Following the recommendations of the manufacturer, we used a serum dilution of $1: 100$ by adding $10 \mu \mathrm{l}$ of serum to $990 \mu \mathrm{l}$ of $1 \times$ PBS. We incubated the plates with $100 \mu \mathrm{l}$ of the diluted sera for $45 \mathrm{~min}$. We removed the sera and washed the wells three times with $200 \mu \mathrm{l}$ of washing solution ( $1 \times$ PBS with $0.1 \%$ Tween). We used Protein A conjugated to horseradish peroxidase (INVITROGEN, Thermo scientific) as the secondary antibody because it has been shown to bind the IgG antibodies of a variety of mammals [45]. We confirmed independently that Protein A was capable of binding to IgG antibodies of bears and mice. We added $100 \mu \mathrm{l}$ of the secondary antibody diluted 1:5000 in 1× PBS and incubated the plates at room temperature for $45 \mathrm{~min}$. We again washed the plates three times with washing solution. We added $100 \mu \mathrm{l}$ of TMB solution (Thermo scientific) to each well to produce a colour reaction. The absorbance was read at a wavelength of $652 \mathrm{~nm}$ every $2 \mathrm{~min}$ for $1 \mathrm{~h}$ with a plate reader (BIO-TEK Instruments, program $\mathrm{KC}^{\text {tix }}$ v3.2).

\section{Detection of antibodies against TBEV}

We used an ELISA assay (FSME (TBE) Microtiter plates IgG) to test whether the bears had developed specific antibodies against TBEV. The ELISA protocol was the same as described for Borrelia. For the positive and negative controls, we used goat serum samples from a previous study [46] in addition to the bear serum samples from the zoological park. The seropositive status of these goat serum samples had been determined using a serum neutralization test, which is considered the gold standard in the diagnosis of TBEV. We found that Protein $G$ was much more effective than Protein A at binding goat IgG. For the TBEV ELISA assay, we therefore used two different secondary antibodies: Protein A for the bear samples and Protein $G$ for the goat samples. 


\section{Collection of tissue samples from bears}

We used quantitative PCR (qPCR) to test bear tissue samples for infection with Borrelia pathogens. We collected tissue samples from 16 bears that had been killed legally by private hunters on different days during the last three weeks of the month of August 2014 in the southern area. No bears were killed for the purpose of this study. For each bear, all tissue samples were collected within a few hours following death from the following organs: skin, liver, kidney, bladder, and arteries. One tissue sample was unusable, resulting in a total of 79 tissue samples. Tissue samples were frozen on ice and brought to the laboratory. We used aseptic dissection to obtain $\sim 25 \mathrm{mg}$ of tissue from each sample. To avoid contamination, we disinfected and autoclaved the dissection tools after dissecting the samples from each bear and cleaned the tools with $70 \%$ ethanol and $5 \%$ bleach between dissecting the different tissues from the same bear. The 25-mg tissue samples were placed in individual Eppendorf tubes $(1.7 \mathrm{ml})$ and were kept at $-20{ }^{\circ} \mathrm{C}$ until further analysis.

\section{DNA extraction of tissue samples}

We extracted the DNA from the bear tissue samples using the DNeasy Blood and Tissue extraction kit (QIAGEN) and following the manufacturer's instructions. We eluted the DNA in $200 \mu \mathrm{l}$ of AE buffer. We also extracted DNA from the ear tissue samples of four laboratory mice that had been infected experimentally with $B$. afzelii (positive controls) and four laboratory mice that had not been infected with B. afzelii (negative controls).

\section{Quantitative PCR}

We used qPCR to detect Borrelia spirochetes in the bear tissue samples. We amplified the flagellin gene (132 bp) of the B. burgdorferi s. l. genospecies complex. Details of the primers and probe, $\mathrm{qPCR}$ reaction mixture, and thermocycling conditions have been described elsewhere $[47,48]$. For amplification we used a LightCycler 96 (Roche Applied Science, Switzerland). The qPCR plates contained 80 bear tissue samples, the 4 mouse positive DNA extraction controls, the 4 mouse negative DNA extraction controls, 3 negative qPCR controls (pure water), and three standards containing $10^{3}, 10^{4}$, and $10^{5}$ copies of the flagellin gene (three standards on each plate). All samples were run in duplicate using two different qPCR plates.

\section{Statistical analysis}

We used the software program $\mathrm{R}$ (version 3.1.2) for the statistical analysis [49]. We calculated the strength of the antibody response against each tick-borne pathogen as the area under the curve of the absorbance versus time plot by using the 'auc' function of the R package 'MESS' [50]. We refer to this antibody response variable as the optical density. The log-transformed optical densities followed a normal distribution. We therefore analysed this response variable as a linear mixed effects model by using the 'Ime' function of the $\mathrm{R}$ package 'nlme' [51]. The log-transformed optical density was modelled as a function of four explanatory variables: study area, age group, year of capture, and bear identity. Study area was a fixed factor with two levels: the northern area and the southern area. Age group was a fixed factor with five levels: yearlings, juveniles, young adults, adults, and old adults. Year of capture was a continuous covariate and was rescaled so that the years 1995 and 2012 corresponded to years 1 and 18, respectively. Bear identity was modelled as a random factor.

We ran 19 candidate models that differed in the structure of the fixed effects, but always with the same random effects structure. The full model contained the three main effects, the three 2-way interactions, and the one 3-way interaction. For the other models, we removed one or more factors and interactions. The corrected Akaike information criterion (AICc) was used to compare models by running the 'dredge' function in the $\mathrm{R}$ package 'MuMIn' [52]. The AICc weight indicated the support for each model. To calculate the support for each explanatory variable, we summed the supports for all the models containing that particular explanatory variable. We used model averaging to calculate a weighted average of the parameter estimates across the set of candidate models. This approach incorporates the uncertainty due to model selection in the calculation of the confidence intervals and provides robust parameter estimates [53].

We tried adding sex as a fourth fixed factor but the models had trouble converging. To test whether the fixed factor sex was important, we repeated the above analyses by replacing the covariate year of capture with the fixed factor sex. All models with the fixed factor sex had lower AICc values than the corresponding models with the fixed factor year of capture. We therefore did not further consider the fixed factor sex in our model selection results.

\section{Repeatability of the optical density}

For the B. burgdorferi s. l. ELISA assay, we estimated the repeatability of the optical density for (1) the bear serum samples (two plates) and (2) the controls (14 plates). For the repeatability of the bear serum samples, we used the data from the randomly selected samples of 80 bear sera that were processed twice in two independent ELISA plates. For the repeatability of the controls, we used the data from the positive and negative controls (four $B$. afzelii-infected laboratory mice, four uninfected laboratory mice, and four brown bears from a zoo) that had been used in all 14 ELISA plates.

We used Pearson's correlation test to determine whether there was a correlation between the optical densities of 
Table 1 Anti-Borrelia lgG values of the Scandinavian brown bears and the negative and positive controls

\begin{tabular}{llllll}
\hline Serum type & $\mathrm{N}$ & Mean & SE & Minimum & Maximum \\
\hline Wild bears & 1172 serum samples (569 individuals) & 43.25 & 0.59 & 10.17 & 130.47 \\
Negative controls & 56 serum samples (4 individuals) & 13.19 & 0.29 & 9.10 & 18.46 \\
Positive controls & 56 serum samples (4 individuals) & 155.09 & 2.76 & 110.60 & 196.43 \\
\hline
\end{tabular}

The negative controls were uninfected laboratory mice and the positive controls were laboratory mice that had been experimentally infected with $B$. afzelii (Jacquet M, Durand J, Rais O, Voordouw M: Cross-reactive acquired immunity influences transmission success of the Lyme disease pathogen, Borrelia afzelii, submitted). The anti-Borrelia lgG response was measured in units of optical density (OD units). The sample size (N), mean optical density, standard error (SE), minimum and maximum values are also shown

the B. burgdorferi s. l. ELISA assay and the TBEV ELISA assay for the same sample.

\section{Results}

Repeatability of the optical density of the Borrelia ELISA assay

For the B. burgdorferi s. 1. ELISA, the repeatability of the optical density between the two plates was 0.85 with the controls $\left(\mathrm{F}_{95}, 96=12.10, p<0.001\right)$ and 0.75 without the controls $\left(\mathrm{F}_{83}, 84=6.96, p<0.001\right)$. Thus there was substantial repeatable variation among the bear serum samples and the measurement error was not very large
(15 to $25 \%$ ). The repeatability of the controls among the 15 plates was $0.99\left(\mathrm{~F}_{11}, 168=1071.00, p<0.001\right)$.

\section{Anti-Borrelia lgG antibody values of the bear sera}

The mean anti-Borrelia IgG antibody value of the bear sera was 3.28 times higher than the negative controls (uninfected mice sera), whereas the mean anti-Borrelia IgG antibody value of the positive controls (infected mice sera) was 11.76 times higher than the negative controls (Table 1). Thus the antibody values of the bear sera were intermediate between the seronegative and seropositive mice sera. The eight bears with the highest antibody values (range $=110.73$ to 130.47 units of optical density)

Table 2 Model selection results of the anti-Borrelia lgG response of the Scandinavian brown bears

\begin{tabular}{|c|c|c|c|c|c|c|c|}
\hline Rank & Fixed effects structure & df & $L L$ & $\mathrm{AlCc}$ & $\Delta \mathrm{AICC}$ & Weight 1 & Weight 2 \\
\hline 1 & $O D \sim S+A+Y+S: A+S: Y$ & 14 & -442.26 & 912.53 & 0.00 & 0.54 & 0.54 \\
\hline 2 & $\mathrm{OD} \sim \mathrm{S}+\mathrm{A}+\mathrm{Y}+\mathrm{S}: \mathrm{A}$ & 13 & -444.28 & 914.55 & 2.02 & 0.20 & 0.74 \\
\hline 3 & $\mathrm{OD} \sim \mathrm{S}+\mathrm{A}+\mathrm{S}: \mathrm{A}$ & 12 & -445.36 & 914.73 & 2.20 & 0.18 & 0.92 \\
\hline 4 & $O D \sim S+A+Y+S: A+S: Y+A: Y+S: A: Y$ & 22 & -437.00 & 917.99 & 5.46 & 0.04 & 0.96 \\
\hline 5 & $O D \sim S+A+Y+S: Y$ & 10 & -449.27 & 918.53 & 6.00 & 0.03 & 0.99 \\
\hline 6 & $O D \sim S+A+Y+S: A+S: Y+A: Y$ & 18 & -442.01 & 920.02 & 7.49 & 0.01 & 1.00 \\
\hline 7 & $O D \sim S+A+Y+S: A+A: Y$ & 17 & -444.04 & 922.09 & 9.56 & 0.00 & 1.00 \\
\hline 8 & $O D \sim S+A+Y$ & 9 & -452.70 & 923.40 & 10.87 & 0.00 & 1.00 \\
\hline 9 & $\mathrm{OD} \sim \mathrm{S}+\mathrm{A}$ & 8 & -453.79 & 923.58 & 11.05 & 0.00 & 1.00 \\
\hline 10 & $O D \sim S+A+Y+S: Y+A: Y$ & 14 & -448.95 & 925.89 & 13.36 & 0.00 & 1.00 \\
\hline 11 & $O D \sim A+Y$ & 8 & -455.03 & 926.06 & 13.53 & 0.00 & 1.00 \\
\hline 12 & $\mathrm{OD} \sim \mathrm{A}$ & 7 & -456.27 & 926.55 & 14.02 & 0.00 & 1.00 \\
\hline 13 & $\mathrm{OD} \sim \mathrm{S}+\mathrm{A}+\mathrm{Y}+\mathrm{A}: \mathrm{Y}$ & 13 & -452.29 & 930.58 & 18.05 & 0.00 & 1.00 \\
\hline 14 & $O D \sim A+Y+A: Y$ & 12 & -454.52 & 933.04 & 20.51 & 0.00 & 1.00 \\
\hline 15 & $O D \sim S+Y+S: Y$ & 6 & -576.20 & 1164.4 & 251.87 & 0.00 & 1.00 \\
\hline 16 & $\mathrm{OD} \sim \mathrm{S}+\mathrm{Y}$ & 5 & -581.93 & 1173.86 & 261.33 & 0.00 & 1.00 \\
\hline 17 & $\mathrm{OD} \sim \mathrm{Y}$ & 4 & -583.91 & 1175.81 & 263.28 & 0.00 & 1.00 \\
\hline 18 & $\mathrm{OD} \sim \mathrm{S}$ & 4 & -586.54 & 1181.07 & 268.54 & 0.00 & 1.00 \\
\hline 19 & $\mathrm{OD} \sim 1$ & 3 & -588.91 & 1183.81 & 271.28 & 0.00 & 1.00 \\
\hline
\end{tabular}

The log-transformed optical density (OD) is a measure of the anti-Borrelia lgG response and was modelled as a linear mixed effects model. Fixed factors included study area $(S)$, age group $(A)$, and capture year $(Y)$, and the random factor was bear identity. Shown for each model are: the model rank (Rank), the structure of the fixed effects, the degrees of freedom (df), the log-likelihood (LL), the corrected Akaike information criterion (AICc), the difference in AICc value from the top model $(\triangle \mathrm{AICC})$, the model weight (Weight 1), and the cumulative weight (Weight 2) 
were higher than the least seropositive mice sera. The antibody values of our ELISA assay suggested that brown bears had been exposed to the Borrelia pathogen.

\section{Model selection}

In our candidate set of 19 models, the confidence set containing the top four models $(1,2,3,4)$ had a combined support of $96.0 \%$ (Table 2). None of the remaining 15 models had more than $3.0 \%$ of the support (Table 2). The top model had 2.7 times more support than the secondbest model (Table 2). There was strong support for the main effects of study area (>99\%), age group (>99\%), and the interaction between study area and age group $(>96 \%)$. There was weaker support for the main effect of capture year $(>82 \%)$ and the interaction between study area and capture year $(>62 \%)$.

\section{Age group and study area}

There was substantial variation in the anti-Borrelia IgG immune antibody response across age groups (Fig. 2). All other age groups had a higher anti-Borrelia IgG antibody response than yearlings (Fig. 2). The immune response in the older age groups was 4.7 to $12.4 \%$ higher than the yearlings, depending on the particular combination of age group and area (Fig. 2). The immune response peaked in the young adult bears (Fig. 2), before declining

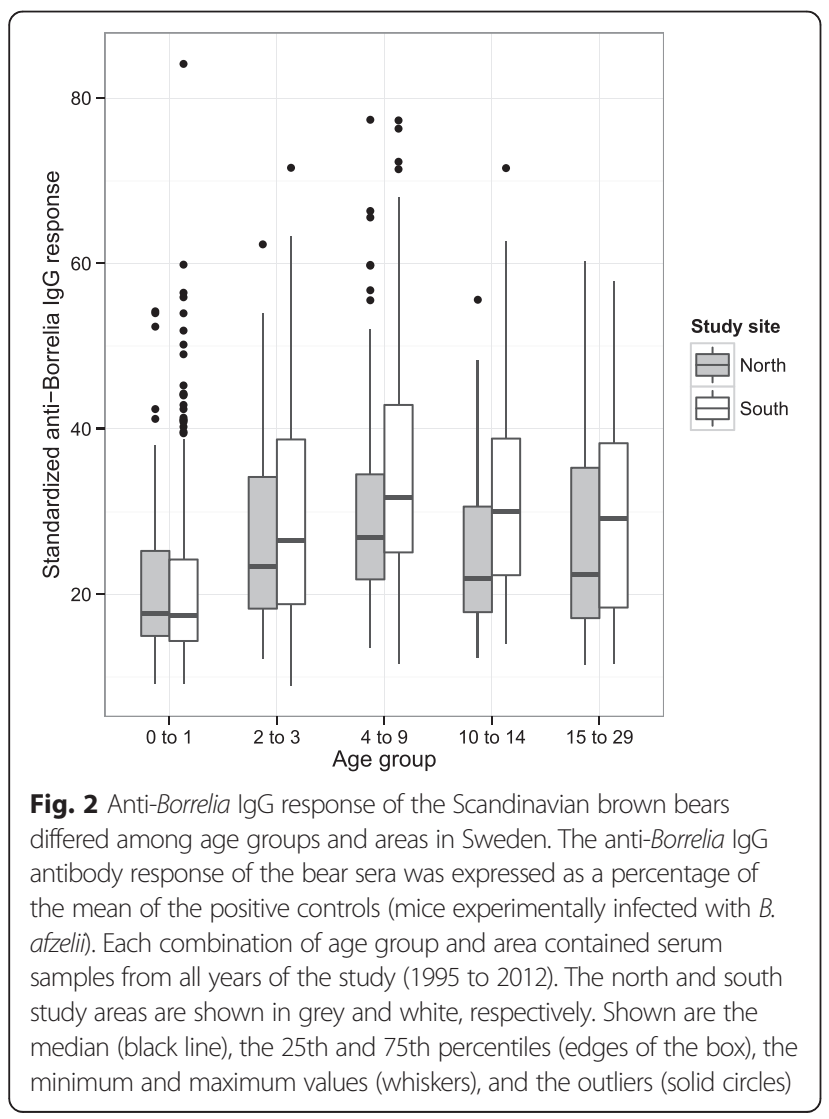

by 1.4 to $5.0 \%$ in the older age classes, depending on the particular combination of age group and area. The immune response in the south was $0.9,2.0$, and $5.6 \%$ higher than the north for the juveniles, young adults and adults, respectively. In contrast, the immune response in the south was 2.3 and $0.1 \%$ lower than the north for the yearlings and old adults, respectively. Our analysis found that age group and study area were important predictors of the anti-Borrelia IgG response in bear sera.

\section{Capture year and study area}

In the southern area, the anti-Borrelia IgG response increased slightly over time (Fig. 3). By contrast, in the northern area there was too much variation among years to detect any temporal trend (Fig. 3). For the yearlings in the northern area, the slope of the regression of the antiBorrelia IgG immune response versus time was essentially zero (slope $=-0.002 \mathrm{OD}$ units/year, $95 \% \mathrm{CL}=-0.013$ to 0.009 OD units/year; Table 3). For the yearlings in the southern area, the slope was positive and greater than that of the yearlings in the northern area (contrast in slope $=$ 0.011 OD units/year, $95 \% \mathrm{CL}$ of the contrast $=-0.001$ to $0.023 \mathrm{OD}$ units/year) and the lower $95 \%$ confidence limit overlapped zero by a very small amount (Table 3 ). Our analysis suggested that the anti-Borrelia IgG response increased over time, but only in the southern study area.

\section{Other interaction terms}

Support for the interaction between capture year and age group was weak. The two models that contained this interaction had a combined support of $5 \%$ (Table 2). Thus there was little evidence that the interaction between capture year and age group influenced variation in the anti-Borrelia IgG response of the bears. Support for the three-way interaction between area, age class, and capture year was also weak. The one model that contained this three-way interaction had a support of $4 \%$ (Table 2).

\section{Repeatability of the optical density of the TBEV ELISA assay}

Difference in background absorbance between the two plates overwhelmed the variance in absorbance among the samples. The repeatability between the two plates was therefore calculated after standardizing the optical density values to $\mathrm{z}$-scores for each plate. For the TBEV ELISA assay, the repeatability of the standardized optical density between the two plates was 0.80 with the controls $\left(\mathrm{F}_{95}, 96=\right.$ 9.24, $p<0.001)$ and 0.58 without the controls $\left(\mathrm{F}_{76}, 77=3.80\right.$, $p<0.001)$. Thus there was substantial repeatable variation among the bear serum samples and the measurement error was moderate (20 to $42 \%$ ). The repeatability of the controls among the 15 plates was $0.97\left(\mathrm{~F}_{10}, 165=\right.$ 462.80, $p<0.001)$. 

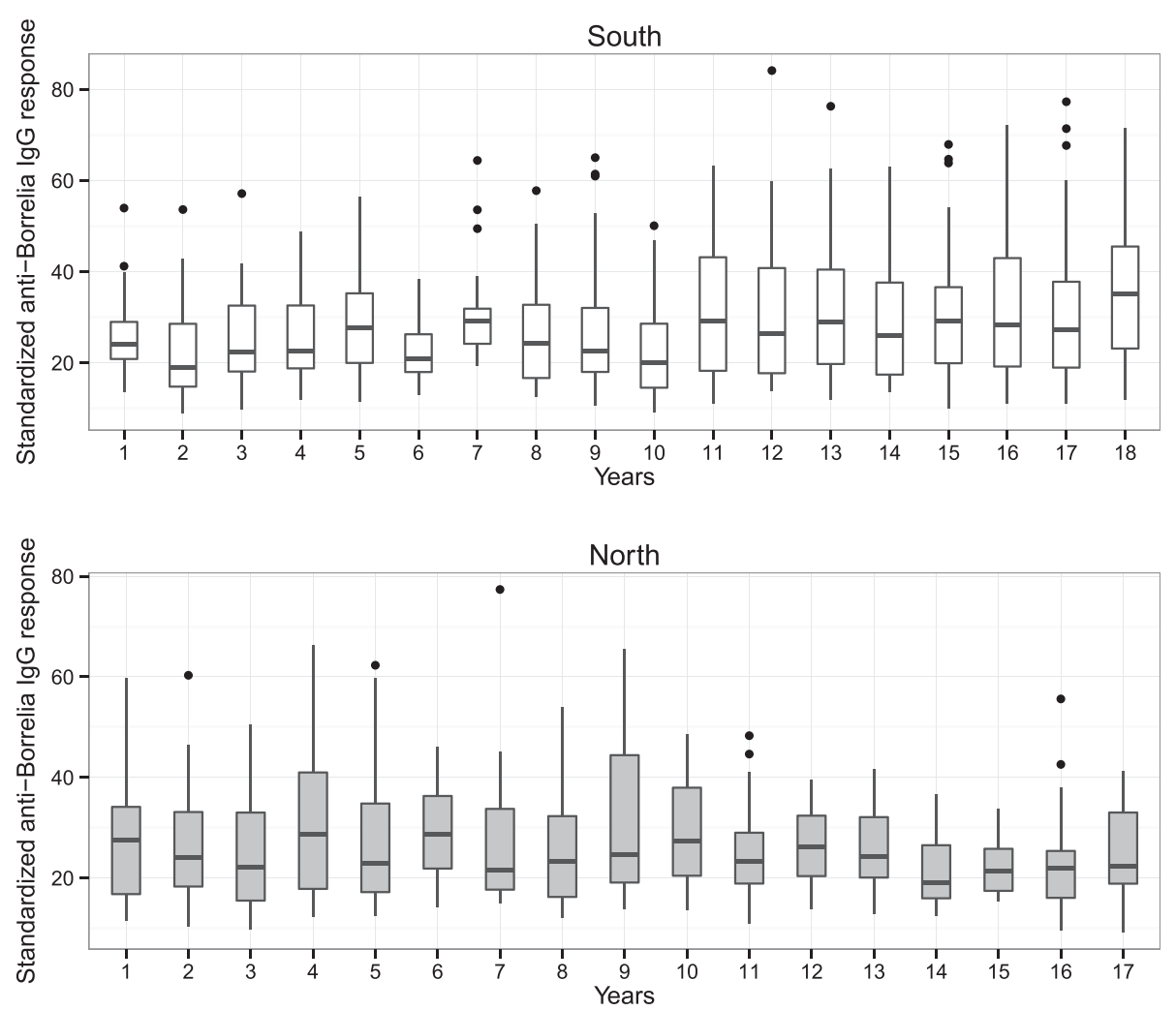

Fig. 3 Anti-Borrelia lgG response of the Scandinavian brown bears over time differed between areas. The anti-Borrelia lgG response in the bear sera is shown for the entire study (year $1=1995$ and year $18=2012$ ). The anti-Borrelia lgG antibody response of the bear sera (optical density) was expressed as a percentage of the mean of the positive controls (mice experimentally infected with B. afzelii). Each combination of age group and area contains serum samples from all age classes. The north and south study areas are shown in grey and white, respectively. Shown are the median (black line), the 25th and 75th percentiles (edges of the box), the minimum and maximum values (whiskers), and the outliers (solid circles)

\section{Anti-TBEV IgG antibody values of the bear sera}

The mean anti-TBEV IgG antibody value of the bear sera was 2.31 times lower than the negative controls (uninfected goat sera) and 16.37 times lower than the positive controls (infected goat sera) (Table 4). The twelve bears with the highest antibody values (range 23.04 to 39.77 units of optical density) were higher than the mean antibody value of the seronegative goat sera (22.75 units of optical density). The ELISA results suggested very weak exposure of brown bears to TBEV and we therefore did not further analyse these data.

\section{Correlation in optical density between Borrelia and TBEV assays}

There was a significant, positive correlation between the anti-Borrelia IgG immune response and the anti-TBEV IgG immune response across the bear serum samples (Pearson's correlation coefficient $=0.156, \mathrm{~N}=1141, p<$ $0.001)$. For the twelve combinations of age group and area, the correlation between the two immune responses was always positive and in some cases statistically significant (Table 5).
Analysis of the bear tissue samples using qPCR

The qPCR worked well, as $90 \%$ of the positive controls tested positive for Borrelia spirochetes (9 positive/10 total; 6/6 standards and 3/4 ear tissue samples from experimentally infected mice tested positive for $B$. afzelii) and all negative controls tested negative. None of the bear tissue samples tested positive for B. burgdorferi s. l. pathogens.

\section{Discussion}

The anti-Borrelia immune response was higher in the southern bears than the northern bears for all age groups (except yearlings and old adults). This pattern is consistent with the geographic distribution of I. ricinus, which is more common in southern Scandinavia where the climate is warmer $[9,11]$. The bears in the southern area were captured primarily in the counties of Dalarna and Gävleborg. In these two counties, populations of $I$. ricinus increased substantially from the early 1990s to 2008 [10]. The bears in the northern area were captured primarily in the northwestern corner of Norbotten County. In 1990, there were reports of I. ricinus in the coastal area of Norrbotten County bordering the Gulf 
Table 3 Model-averaged parameter estimates of the anti-Borrelia lgG response of the Scandinavian brown bears

\begin{tabular}{|c|c|c|c|c|c|c|c|c|}
\hline Parameter & Model-averaged coefficients & Estimate & $\%$ Change & SE & Adj SE & z value & $p$ & Sig \\
\hline Intercept $^{a}$ & Intercept (yearlings in northern area) & 3.421 & & 0.0574 & 0.0575 & 59.513 & $<0.0001$ & *** \\
\hline Contrast & Juveniles & 0.216 & $6.3 \%$ & 0.0613 & 0.0614 & 3.524 & 0.0004 & *** \\
\hline Contrast & Young adults & 0.350 & $10.2 \%$ & 0.0531 & 0.0532 & 6.569 & $<0.0001$ & *** \\
\hline Contrast & Adults & 0.160 & $4.7 \%$ & 0.0871 & 0.0872 & 1.832 & 0.0669 & \\
\hline Contrast & Old adults & 0.237 & $6.9 \%$ & 0.1240 & 0.1242 & 1.91 & 0.0561 & \\
\hline Contrast & Southern area & -0.079 & $-2.3 \%$ & 0.0790 & 0.0791 & 0.994 & 0.3202 & \\
\hline Contrast & Juveniles in southern area & 0.113 & $3.3 \%$ & 0.0724 & 0.0725 & 1.559 & 0.1189 & \\
\hline Contrast & Young adults in southern area & 0.154 & $4.5 \%$ & 0.0643 & 0.0645 & 2.389 & 0.0169 & * \\
\hline Contrast & Adults in southern area & 0.292 & $8.5 \%$ & 0.0997 & 0.0999 & 2.92 & 0.0035 & ** \\
\hline Contrast & Old adults in southern area & 0.074 & $2.2 \%$ & 0.1552 & 0.1555 & 0.477 & 0.6335 & \\
\hline Slope ${ }^{b}$ & Capture year (yearlings in northern area) & -0.002 & & 0.0054 & 0.0054 & 0.315 & 0.7525 & \\
\hline Contrast & Capture year in southern area & 0.011 & $0.3 \%$ & 0.0059 & 0.0059 & 1.942 & 0.0521 & \\
\hline Contrast & Capture year in juveniles & 0.006 & $0.2 \%$ & 0.0108 & 0.0108 & 0.571 & 0.5681 & \\
\hline Contrast & Capture year in young adults & -0.003 & $-0.1 \%$ & 0.0095 & 0.0095 & 0.306 & 0.7595 & \\
\hline Contrast & Capture year in adults & 0.014 & $0.4 \%$ & 0.0147 & 0.0147 & 0.95 & 0.3421 & \\
\hline Contrast & Capture year in old adults & 0.024 & $0.6 \%$ & 0.0195 & 0.0195 & 1.217 & 0.2238 & \\
\hline Contrast & Capture year in juveniles in southern area & -0.011 & $-0.3 \%$ & 0.0133 & 0.0133 & 0.858 & 0.3907 & \\
\hline Contrast & Capture year in young adults in southern area & 0.010 & $0.3 \%$ & 0.0122 & 0.0122 & 0.816 & 0.4145 & \\
\hline Contrast & Capture year in adults in southern area & -0.025 & $-0.7 \%$ & 0.0172 & 0.0172 & 1.43 & 0.1529 & \\
\hline Contrast & Capture year in old adults in southern area & -0.043 & $-1.3 \%$ & 0.0215 & 0.0215 & 2.019 & 0.0434 & * \\
\hline
\end{tabular}

The parameter estimates for the anti-Borrelia IgG response of the brown bears were averaged over the candidate models in Table 2. Anti-Borrelia IgG values were measured in units of optical density (OD units) and were modelled as a function of study area, age group, capture year and their interactions. The intercept and slope are defined for the reference group (yearling bears in the northern area). The contrasts refer to the difference in the intercepts (or slopes) between each particular combination of age group and area and the reference group. The percentage change (\% Change) expresses each contrast as a percentage of the intercept (3.421 OD units). Also shown are the standard error (SE), the adjusted standard error (Adj SE), the $z$ value, the $p$ value ( $p$ ), and the statistical significance (Sig) antercept refers to the mean OD for the yearling bears in the northern area

bSlope refers to the change in OD per year for the yearling bears in the northern area

Significance codes: ${ }^{\prime * * * \prime}=p<0.001 ;^{\prime * * \prime}=0.001<p<0.010{ }^{\prime * \prime}=0.010<p<0.050$

of Bothnia [10]. In 2008, I. ricinus was reported in central Norbotten County, and this focus overlapped with some of the sampling locations of the bears. In summary, the range maps of I. ricinus in the study by Jaenson et al. [10] suggest that the bears in the southern area are more likely to encounter ticks than the bears in the northern area. Furthermore, stable, high-density populations of ticks are more favourable for the introduction and maintenance of tick-borne pathogens [54]. The higher anti-Borrelia IgG response in the southern bears was therefore consistent with the expected higher abundance of ticks in southern Scandinavia. We also found that the anti-Borrelia IgG immune response in the bear population was much stronger than the anti-TBEV IgG immune response. This difference was not surprising because Borrelia pathogens are much more common than TBEV in populations of I. ricinus ticks [20].

The mean anti-Borrelia IgG immune response in the bears increased over time, but only in the southern area. This observation is consistent with the literature documenting that the prevalence of ticks and tick-borne diseases (e.g. LB and TBE) has increased in Scandinavia over the last three decades $[1-7,9,14]$. Numerous authors have suggested that climate change is causing this increased burden of tick-borne diseases $[11,55,56]$, whereas others have argued against this view [3, 19]. The temporal increase in anti-Borrelia IgG levels in the

Table 4 Anti-TBEV IgG values of the Scandinavian brown bears and the negative and positive controls

\begin{tabular}{llrrrr}
\hline Serum type & N & Mean & SE & Minimum & Maximum \\
\hline Wild bears & 1172 serum samples (569 individuals) & 9.86 & 0.11 & 1.93 & 39.77 \\
Negative controls & 60 serum samples (4 individuals) & 22.75 & 0.99 & 7.59 & 47.53 \\
Positive controls & 60 serum samples (4 individuals) & 161.37 & 2.85 & 82.84 & 185.83 \\
\hline
\end{tabular}

The negative controls were uninfected goats and the positive controls were goats that tested positive for TBEV [46]. The anti-TBEV IgG response is measured in units of optical density (OD units). The sample size (N), mean optical density, standard error (SE), minimum and maximum values are also shown 
Table 5 Correlation in optical density for Borrelia and TBEV ELISA assays in the Scandinavian brown bears

\begin{tabular}{lllll}
\hline Area & Age group & $N$ & $r$ & $p$ \\
\hline North & Yearlings (0-1) & 124 & 0.066 & 0.4642 \\
North & Juveniles (2-3) & 58 & 0.110 & 0.4101 \\
North & Young (4-5) & 56 & 0.188 & 0.1661 \\
North & Middle (6-9) & 86 & 0.409 & $<0.0001$ \\
North & Old (10-14) & 40 & 0.126 & 0.4398 \\
North & Older (15-29) & 20 & 0.188 & 0.4265 \\
South & Yearlings (0-1) & 245 & 0.130 & 0.0414 \\
South & Juveniles (2-3) & 130 & 0.198 & 0.0240 \\
South & Young (4-5) & 114 & 0.175 & 0.0631 \\
South & Middle (6-9) & 129 & 0.069 & 0.4340 \\
South & Old (10-14) & 86 & 0.171 & 0.1164 \\
South & Older (15-29) & 53 & 0.341 & 0.0124 \\
\hline
\end{tabular}

Pearson's correlation coefficient for the optical density between the Borrelia and TBEV assays is positive for all 12 combinations of age group and area for brown bears in Sweden. The area, age group, sample size (N), Pearson's correlation coefficient $(r)$ and $p$-value $(p)$ are shown

southern bears over the last 18 years is consistent with an increased abundance of Borrelia-infected ticks in southern Scandinavia. An alternative explanation for the time-dependent increase in the anti-Borrelia immune response is time-dependent, cumulative damage to the bear serum samples. However, if this explanation was true, we should have observed the same timedependent increase in the anti-Borrelia IgG response in the northern area.

The older bears generally had a stronger anti-Borrelia IgG immune response than younger bears. Age-related increases in seropositive status are commonly observed, because the probability of encountering a pathogen increases throughout an individual's lifetime [57, 58]. Similar patterns have been observed in wild mice, where adult individuals typically have higher anti-Borrelia IgG levels than sexually immature individuals $[59,60]$. The observation that the anti-Borrelia IgG immune response increased over the first three age classes may be explained by the development of the immune system. Mammals build up their immune system by encountering a wide variety of pathogens during development [61, 62]. The decrease in the immune response of the older bears suggests immuno-senescence. Such age-related declines in the acquired immune response also have been observed in human populations $[63,64]$.

Ixodes ticks are capable of feeding on bears [26, 29, 65-68]. Numerous studies in North America have collected I. scapularis and other tick species from the American black bear (Ursus americanus) [26, 28, 29, 65, 66]. Serological studies further suggest that $U$. americanus is frequently exposed to Borrelia pathogens [69, 70]. A molecular screening of brown bears in Slovakia found that $24.3 \%$ $(18 / 74)$ of the animals tested were positive for the tickborne pathogen Anaplasma phagocytophilum [67]. A serological survey of brown bears in Slovakia found that $65.2 \%(15 / 23)$ of the animals were seropositive for A. phagocytophilum [68]. As I. ricinus is the principal vector of $A$. phagocytophilum, these two studies provide indirect evidence that $I$. ricinus ticks are capable of feeding on brown bears $[67,68]$.

Mammalian hosts differ substantially in their ability to maintain systemic infections with Borrelia pathogens [71]. Competent hosts, such as rodents, can maintain long-lived, chronic infections in their tissues [72, 73]. Incompetent hosts, such as deer, do not develop systemic infections [74-76], but such hosts can still develop a strong antibody response to Borrelia pathogens [77, 78]. Whether or not bears are competent hosts for Borrelia pathogens is currently unknown. A study on Lyme disease in the American black bear isolated spirochetes from blood and kidney samples, but no PCR was conducted to confirm pathogen identity [26]. In our study, none of the tissue samples from the 16 bears tested positive for B. burgdorferi s. l. DNA. Consistent with our results, previous studies also have shown that bears develop antibodies against Borrelia pathogens $[69,70]$. It is possible that bears, like deer, may act as sentinel hosts for Borrelia pathogens without developing a systemic infection.

Cross-immunity is a potentially confounding factor in any serological survey. Antibodies developed against other pathogens could be cross-reactive with the antigens used in our assays. For example, antibodies developed against Treponema sp. in humans can crossreact with the antigens of Borrelia burgdorferi s. 1 . pathogens $[79,80]$. Thus we cannot exclude the possibility that unknown microbial pathogens of the brown bear may have contributed to the background absorbance observed in the serum samples of this study. Future studies should use immunoblotting to further confirm the specificity of the anti-Borrelia IgG antibody response in brown bears and other wild animal populations.

\section{Conclusions}

Our long-term serological study of the Scandinavian brown bear provides evidence consistent with the observation that ticks and tick-borne pathogens are expanding their abundance and prevalence, respectively, in northern Europe. Bears in the southern area, where I. ricinus ticks have been reported, had higher values of anti-Borrelia IgG antibodies than bears at the northern area, where I. ricinus ticks are believed to be less common. Over the 18 years of the study, the value 
of anti-Borrelia IgG antibodies increased in the southern area, but not the northern area. Our study suggests that long-term serological monitoring of large mammals can provide insight into changes in the distribution of ticks and tick-borne diseases, and perhaps the reasons for these changes.

\section{Abbreviations}

AICc: Akaike information criterion; LB: Lyme borreliosis; TBE: tick-borne encephalitis; TBEV: tick-borne encephalitis virus.

\section{Competing interests}

The authors declare that they have no competing interests.

\section{Authors' contributions}

ALE, KL, and JMA initiated this study. JES and JMA are chief scientists of the Scandinavian Brown Bear Research Project. JES, JMA, ALE, and KLJ all participated in the collection of serum samples. JMA and ALE planned the blood sampling and biobanking of the bears. KLJ organized the biobank, sorted the serum samples and transported them to Switzerland. JB collected the bear tissue samples for PCR analysis. LP, RL, and MJV planned the immunological component of the study. LP conducted the ELISA and PCR assays. MJ experimentally infected the mice with $B$. afzelii via tick bite and provided the positive control sera. LP and MJV conducted the statistical analyses and wrote the manuscript. MB created the map of the bear sampling locations. All authors helped edit the manuscript. All authors read and approved the final manuscript.

\section{Acknowledgments}

This work was supported by a grant from the Swiss National Science Foundation (SNSF) to Maarten Voordouw (FN 31003A_141153) and was conducted within the Scandinavian Brown Bear Research Project, which was funded primarily by the Swedish Environmental Protection Agency, Norwegian Environment Agency, and Austrian Research Council. This is paper number 189 from the Scandinavian Brown Bear Research Project. We thank Kheirie Kabalan for help with the laboratory work, and Nadia Rieille for providing the serum of the uninfected and TBEV-infected goats. The members of the working group 'Tiques et Maladies à Tiques' (GDR REID) provided insightful discussions. Thanks to three anonymous reviewers for comments on this manuscript. This study is part of the Master thesis of Lye Paillard.

\section{Author details \\ 'Laboratory of Ecology and Evolution of Parasites, Institute of Biology, University of Neuchâtel, Rue Emile-Argand 11, 2000 Neuchâtel, Switzerland. ${ }^{2}$ Department of Forestry and Wildlife Management, Faculty of Forestry and Wildlife Management, Hedmark University College, Campus Evenstad, NO-2418, Elverum, Norway. ${ }^{3}$ ADMED Microbiologie, Boucle de Cydalise 16 2300 la Chaux-de-Fonds, Switzerland. ${ }^{4}$ Informatics and Telematics Service, University of Neuchâtel, Rue Emile-Argand 11, 2000 Neuchâtel, Switzerland. ${ }^{5}$ Department of Wildlife, Fish and Environmental Studies, Faculty of Forest Sciences, Swedish University of Agricultural Sciences, SE-901 83 Umeå, Sweden. ${ }^{6}$ Department of Ecology and Natural Resources Management, Norwegian University of Life Sciences, Postbox 5003NO-1432 Ås, Norway. ${ }^{7}$ Norwegian Institute for Nature Research, NO-7485 Trondheim, Norway.}

Received: 8 May 2015 Accepted: 25 June 2015

Published online: 28 July 2015

\section{References}

1. Knap N, Avsic-Zupanc T. Correlation of TBE incidence with red deer and roe deer abundance in Slovenia. PLoS One. 2013;8:6.

2. Rizzoli A, Hauffe HC, Carpi G, Vourc'h Gl, Neteler M, Rosa R. Lyme borreliosis in Europe. Eurosurveillance. 2011;16(27):2-9.

3. Randolph SE. Evidence that climate change has caused 'emergence' of tickborne diseases in Europe? Int J Med Microbiol. 2004:293:5-15.

4. Gilbert L. Altitudinal patterns of tick and host abundance: a potential role for climate change in regulating tick-borne diseases? Oecologia. 2010;162(1):217-25.
5. Gray JS. Ixodes ricinus seasonal activity: Implications of global warming indicated by revisiting tick and weather data. Int J Med Microbiol. 2008;298:19-24.

6. Leger E, Vourc'h G, Vial L, Chevillon C, McCoy KD. Changing distributions of ticks: causes and consequences. Exp Appl Acarol. 2013;59(1-2):219-44.

7. Medlock JM, Hansford KM, Bormane A, Derdakova M, Estrada-Pena A, George J-C, et al. Driving forces for changes in geographical distribution of Ixodes ricinus ticks in Europe. Parasites Vectors. 2013;6.

8. Jaenson TGT, Hjertqvist M, Bergstrom $T$, Lundkvist A. Why is tick-borne encephalitis increasing? A review of the key factors causing the increasing incidence of human TBE in Sweden. Parasites Vectors. 2012;5.

9. Jore $S$, Viljugrein $H$, Hofshagen M, Brun-Hansen H, Kristoffersen AB, Nygard K, et al. Multi-source analysis reveals latitudinal and altitudinal shifts in range of Ixodes ricinus at its northern distribution limit. Parasites Vectors. 2011;4.

10. Jaenson TGT, Jaenson DGE, Eisen L, Petersson E, Lindgren E. Changes in the geographical distribution and abundance of the tick Ixodes ricinus during the past 30 years in Sweden. Parasites Vectors. 2012;5.

11. Lindgren $\mathrm{E}$, Talleklint $\mathrm{L}$, Polfeldt $\mathrm{T}$. Impact of climatic change on the northern latitude limit and population density of the disease-transmitting European tick Ixodes ricinus. Environ Health Perspect. 2000;108(2):119-23.

12. Danielova V, Schwarzova L, Materna J, Daniel M, Metelka L, Holubova J, et al. Tick-borne encephalitis virus expansion to higher altitudes correlated with climate warming. Int J Med Microbiol. 2008;298:68-72.

13. Kriz B, Benes C, Danielova V, Daniel M. Socio-economic conditions and other anthropogenic factors influencing tick-borne encephalitis incidence in the Czech Republic. Int J Med Microbiol. 2004:293:63-8.

14. Materna J, Daniel M, Metelka L, Harcarika J. The vertical distribution, density and the development of the tick Ixodes ricinus in mountain areas influenced by climate changes (The Krkonose Mts., Czech Republic). Int J Med Microbiol. 2008;298:25-37.

15. Rizzoli A, Hauffe HC, Tagliapietra V, Neteler M, Rosa R. Forest structure and roe deer abundance predict tick-borne encephalitis risk in Italy. Plos One. 2009:4:2.

16. Bennet $L$, Halling A, Berglund J. Increased incidence of Lyme borreliosis in southern Sweden following mild winters and during warm, humid summers. Eur J Clin Microbiol Infect Dis. 2006:25(7):426-32.

17. Jaenson TGT, Lindgren $\mathrm{E}$. The range of Ixodes ricinus and the risk of contracting Lyme borreliosis will increase northwards when the vegetation period becomes longer. Ticks Tick-Borne Dis. 2011;2(1):44-9.

18. Jaenson TGT, Eisen L, Comstedt P, Mejlon HA, Lindgren E, Bergstrom S, et al. Risk indicators for the tick Ixodes ricinus and Borrelia burgdorferi sensu lato in Sweden. Med Vet Entomol. 2009;23(3):226-37.

19. Randolph SE. To what extent has climate change contributed to the recent epidemiology of tick-borne diseases? Vet Parasitol. 2010;167(2-4):92-4.

20. Randolph SE. The shifting landscape of tick-borne zoonoses: tick-borne encephalitis and Lyme borreliosis in Europe. Philos Trans R Soc Lond B Biol Sci. 2001;356(1411):1045-56.

21. Sumilo D, Bormane A, Asokliene L, Vasilenko V, Golovljova I, Avsic-Zupanc T, et al. Socio-economic factors in the differential upsurge of tick-borne encephalitis in central and eastern Europe. Rev Med Virol. 2008;18(2):81-95.

22. Balling A, Plessow U, Beer M, Pfeffer M. Prevalence of antibodies against tick-borne encephalitis virus in wild game from Saxony, Germany. Ticks Tick-Borne Dis. 2014:5(6):805-9.

23. Ebani W, Bertelloni F, Torracca B, Cerri D. Serological survey of Borrelia burgdorferi sensu lato, Anaplasma phagocytophilum, and Ehrlichia canis infections in rural and urban dogs in central Italy. Ann Agric Environ Med. 2014;21(4):671-5.

24. Foley JE, Queen EV, Sacks B, Foley P. GIS-facilitated spatial epidemiology of tick-borne diseases in coyotes (Canis latrans) in northern and coastal California. Comp Immunol Microbiol Infect Dis. 2005;28(3):197-212.

25. Krause PJ, Telford SR, Ryan R, Hurta AB, Kwasnik I, Luger S, et al. Geographical and temporal distribution of babesial infection in Connecticut. J Clin Microbiol. 1991;29(1):1-4

26. Kazmierczak JJ, Amundson TE, Burgess EC. Borreliosis in free-ranging black bears from Wisconsin. J Wildl Dis. 1988;24(2):366-8.

27. Murray DL, Kapke CA, Evermann JF, Fuller TK. Infectious disease and the conservation of free-ranging large carnivores. Anim Conserv. 1999;2(4):241-54.

28. Rogers LL. Parasites of black bears of the Lake Superior region. J Wildl Dis. 1975;11(2):189-92.

29. Yabsley MJ, Nims TN, Savage MY, Durden LA. Ticks and tick-borne pathogens and putative symbionts of black bears (Ursus americanus floridanus) from Georgia and Florida. J Parasitol. 2009;95(5):1125-8. 
30. Andreassen A, Jore $S$, Cuber $P$, Dudman $S$, Tengs $T$, Isaksen $K$, et al. Prevalence of tick borne encephalitis virus in tick nymphs in relation to climatic factors on the southern coast of Norway. Parasites Vectors. 2012;5.

31. Berglund J, Eitrem R, Ornstein $\mathrm{K}$, Lindberg A, Ringner A, Elmrud $\mathrm{H}$, et al. An epidemiologic study of Lyme-disease in southern Sweden. N Engl J Med. 1995;333(20):1319-24.

32. Csango PA, Blakstad E, Kirtz GC, Pedersen JE, Czettel B. Tick-borne encephalitis in southern Norway. Emerg Infect Dis. 2004;10(3):533-4.

33. Haglund M. Occurrence of TBE in areas previously considered being nonendemic: Scandinavian data generate an international study by the International Scientific Working Group for TBE (ISW-TBE). Int J Med Microbiol. 2002;291:50-4.

34. Soleng A, Kjelland V. Borrelia burgdorferi sensu lato and Anaplasma phagocytophilum in Ixodes ricinus ticks in Bronnoysund in northern Norway. Ticks Tick-Borne Dis. 2013;4(3):218-21.

35. Burri C, Korva M, Bastic V, Knap N, Avsic-Zupanc T, Gern L. Serological evidence of tick-borne encephalitis virus infection in rodents captured at four sites in Switzerland. J Med Entomol. 2012;49(2):436-9.

36. Magnarelli LA. Serologic diagnosis of Lyme-disease. Ann N Y Acad Sci. 1988:539:154-61.

37. Wilske B, Fingerle V, Schulte-Spechtel U. Microbiological and serological diagnosis of Lyme borreliosis. FEMS Immunol Med Microbiol. 2007:49(1):13-21.

38. Arnemo JM, Ahlqvist P, Andersen R, Berntsen F, Ericsson G, Odden J, et al. Risk of capture-related mortality in large free-ranging mammals: experiences from Scandinavia. Wildl Biol. 2006;12(1):109-13.

39. Alonso S, Marquez FJ, Solano-Gallego L. Borrelia burgdorferi serosurvey in wild deer in England and Wales. Vector-Borne Zoonotic Dis. 2012;12(6):448-55.

40. Asbakk K, Aars J, Derocher AE, Wiig O, Oksanen A, Born EW, et al. Serosurvey for Trichinella in polar bears (Ursus maritimus) from Svalbard and the Barents sea. Vet Parasitol. 2010;172(3-4):256-63.

41. Deruaz D, Eid P, Deruaz J, Sempere A, Bourgouin C, Rodhain F, et al. Use of enzyme-labelled protein $\mathrm{G}$ assay for the detection of anti Borrelia burgdorferi antibodies in wild animal sera. Eur J Epidemiol. 1996;12(5):515-9.

42. Inoshima $Y$, Shimizu $S$, Minamoto $N$, Hirai $K$, Sentsui $H$. Use of protein $A G$ in an enzyme-linked immunosorbent assay for screening for antibodies against parapoxvirus in wild animals in Japan. Clin Diagn Lab Immunol. 1999;6(3):388-91.

43. Rah H, Chomel BB, Follmann EH, Kasten RW, Hew CH, Farver TB, et al. Serosurvey of selected zoonotic agents in polar bears (Ursus maritimus). Vet Rec. 2005;156(1):7-13.

44. Tryland M, Derocher AE, Wiig O, Godfroid J. Brucella sp antibodies in polar bears from Svalbard and the Barents sea. J Wildl Dis. 2001;37(3):523-31.

45. Stobel K, Schonberg A, Staak C. A new non-species dependent ELISA for detection of antibodies to Borrelia burgdorferi s. I. in zoo animals. Int J Med Microbiol. 2002;291:88-99.

46. Rieille N, Bressanelli S, Freire CCM, Arcioni S, Gern L, Peter O, et al. Prevalence and phylogenetic analysis of tick-borne encephalitis virus (TBEV) in field-collected ticks (Ixodes ricinus) in southern Switzerland. Parasites Vectors. 2014;7.

47. Berret J, Voordouw MJ. Lyme disease bacterium does not affect attraction to rodent odour in the tick vector. Parasites \& Vectors. 2015:8.

48. Schwaiger M, Peter O, Cassinotti P. Routine diagnosis of Borrelia burgdorferi (sensu lato) infections using a real-time PCR assay. Clin Microbiol Infect. 2001;7(9):461-9.

49. Team RC. R: A language and environment for statistical computing. Vienna, Austria: R Foundation for Statistical Computing; 2014

50. Ekstrom C. MESS: Miscellaneous Esoteric Statistical Scripts. In: R package version 0.3-2 edn. 2014

51. Pinheiro J, Bates D, DebRoy S, Sarkar D, Team RC. nlme: Linear and Nonlinear Mixed Effects Models. In: R package version 3.1-117 edn. 2014.

52. Bartoń K. MuMln: Multi-Model Inference. In: R package version 1.12.1 edn. 2014.

53. Johnson JB, Omland KS. Model selection in ecology and evolution. Trends Ecol Evol. 2004;19(2):101-8.

54. Stafford KC, Cartter ML, Magnarelli LA, Ertel SH, Mshar PA. Temporal correlations between tick abundance and prevalence of ticks infected with Borrelia burgdorferi and increasing incidence of Lyme disease. J Clin Microbiol. 1998:36(5):1240-4.

55. Leighton PA, Koffi JK, Pelcat $Y$, Lindsay LR, Ogden NH. Predicting the speed of tick invasion: an empirical model of range expansion for the Lyme disease vector Ixodes scapularis in Canada. J Appl Ecol. 2012;49(2):457-64
56. Ogden NH, Maarouf A, Barker IK, Bigras-Poulin M, Lindsay LR, Morshed $M G$, et al. Climate change and the potential for range expansion of the Lyme disease vector Ixodes scapularis in Canada. Int J Parasitol. 2006;36(1):63-70

57. Behnke JM, Lewis JW, Zain SNM, Gilbert FS. Helminth infections in Apodemus sylvaticus in southern England: interactive effects of host age, sex and year on the prevalence and abundance of infections. J Helminthol. 1999;73(1):31-44

58. Benavides JA, Huchard E, Pettorelli N, King AJ, Brown ME, Archer CE, et al. From parasite encounter to infection: Multiple-scale drivers of parasite richness in a wild social primate population. Am J Phys Anthropol. 2012;147(1):52-63.

59. Bunikis J, Tsao J, Luke CJ, Luna MG, Fish D, Barbour AG. Borrelia burgdorferi infection in a natural population of Peromyscus leucopus mice: A longitudinal study in an area where Lyme borreliosis is highly endemic. J Infect Dis. 2004;189(8):1515-23.

60. Hofmeister EK, Ellis BA, Glass GE, Childs JE. Longitudinal study of infection with Borrelia burgdorferi in a population of Peromyscus leucopus at a Lyme disease-enzootic site in Maryland. Am J Trop Med Hyg. 1999;60(4):598-609.

61. Day MJ. Immune system development in the dog and cat. J Comp Pathol. 2007;137:S10-5.

62. Holt PG, Jones CA. The development of the immune system during pregnancy and early life. Allergy. 2000;55(8):688-97.

63. Pawelec $G$, Koch S, Franceschi C, Wikby A. Human immunosenescence does it have an infectious component? In: Rattan S, Kristensen P, Clark BFC, editors. Understanding and Modulating Aging. 1067th ed. 2006. p. 56-65.

64. Solana R, Pawelec G, Tarazona R. Aging and innate immunity. Immunity. 2006:24(5):491-4.

65. Leydet Jr BF, Liang F-T. Detection of human bacterial pathogens in ticks collected from Louisiana black bears (Ursus americanus luteolus). Ticks Tick-Borne Dis. 2013;4(3):191-6.

66. Manville AM. Ecto-parasite and endoparasite of black bear in northern Wisconsin. J Wildl Dis. 1978;14(1):97-101.

67. Vichova B, Majlathova V, Novakova M, Straka M, Pet'ko B. First molecular detection of Anaplasma phagocytophilum in european brown bear (Ursus arctos). Vector-Borne Zoonotic Dis. 2010;10(5):543-5.

68. Zele D, Avbersek J, Gruntar I, Ocepek M, Vengust G. Evidence of Anaplasma phagocytophilum in game animals from Slovenia. Acta Vet Hung. 2012;60(4):441-8.

69. Bronson E, Spiker H, Driscoll CP. Serosurvey for selected pathogens in freeranging american black bears (Ursus americanus) in Maryland, USA. J Wildl Dis. 2014;50(4):829-36.

70. Schultz SM, Nicholson WL, Comer JA, Childs JE, Humphreys JG. Serologic evidence of infection with granulocytic ehrlichiae in black bears in Pennsylvania. J Wildl Dis. 2002;38(1):47-53.

71. Gern L, Estrada-Pena A, Frandsen F, Gray JS, Jaenson TGT, Jongejan F, et al European reservoir hosts of Borrelia burgdorferi sensu lato. Zentralbl Bakteriol. 1998;287(3):196-204.

72. Gern L, Siegenthaler M, Hu CM, Leubagarcia S, Humair PF, Moret J. Borrelia burgdorferi in rodents (Apodemus flavicollis and A. sylvaticus) duration and enhancement of infectivity for Ixodes ricinus ticks. Eur J Epidemiol. 1994;10(1):75-80

73. Humair PF, Rais O, Gern L. Transmission of Borrelia afzelii from Apodemus mice and Clethrionomys voles to Ixodes ricinus ticks: differential transmission pattern and overwintering maintenance. Parasitology. 1999;118:33-42

74. Jaenson TGT, Talleklint $L$. Incompetence of roe deer as reservoirs of the Lyme borreliosis spirochete. J Med Entomol. 1992;29(5):813-7.

75. Matuschka FR, Heiler M, Eiffert $H$, Fischer $P$, Lotter $H$, Spielman A Diversionary role of hoofed game in the transmission of Lyme-disease spirochetes. Am J Trop Med Hyg. 1993;48(5):693-9.

76. Telford SR, Mather TN, Moore SI, Wilson ML, Spielman A. Incompetence of deer as reservoirs of the Lyme-disease spirochete. Am J Trop Med Hyg. 1988;39(1):105-9.

77. Kirchgessner MS, Freer H, Whipps CM, Wagner B. Detection of Borrelia burgdorferi outer surface protein antibodies in wild white-tailed deer (Odocoileus virginianus) in New York and Pennsylvania, USA. Vet Immunol Immunopathol. 2013;153(1-2):165-9.

78. Magnarelli LA, Williams SC, Fikrig E. Seasonal prevalence of serum antibodies to whole cell and recombinant antigens of Borrelia burgdorferi and Anaplasma phagocytophilum in white-tailed deer in Connecticut. J Wildl Dis. 2010;46(3):781-90. 
79. Magnarelli LA, Anderson JF, Johnson RC. Cross-reactivity in serological tests for Lyme-disease and other spirochetal infections. J Infect Dis. 1987;156(1):183-8.

80. Magnarelli LA, Miller JN, Anderson JF, Riviere GR. Cross-reactivity of nonspecific treponemal antibody in serologic tests for Lyme-disease. J Clin Microbiol. 1990;28(6):1276-9.

Submit your next manuscript to BioMed Central and take full advantage of:

- Convenient online submission

- Thorough peer review

- No space constraints or color figure charges

- Immediate publication on acceptance

- Inclusion in PubMed, CAS, Scopus and Google Scholar

- Research which is freely available for redistribution 